\title{
Research on the Innovation of Party Building Work in Colleges and
}

\author{
Universities Based on the Internet
}

\author{
Wenming $\mathrm{Yu}^{1, \mathrm{a}}$ \\ ${ }^{1}$ Huaiyin Institute of Technology, Jiangsu Huai'an, 223001, China \\ a email
}

Keywords: Internet; Party building in colleges and universities; Innovation; integration strategy

\begin{abstract}
With the continuous development of the network information society and deepening reform of higher education, party building work in colleges and universities is facing new opportunities and challenges. Based on the author' working and teaching experience for many years, this paper analyzes practical significance to promote the innovation of party building work and discusses current problems on strengthening party building work in colleges and universities by means of the Internet. Finally, the paper proposes measures to improve the innovation of party building with the help of Internet.
\end{abstract}

\section{Introduction}

Promoting the innovation of party building work in colleges and universities with the aid of the Internet has important practical significance in recent years. Party building work in colleges and universities is still in the start stage and there are many shortcomings. Currently, we should combine features of the Internet with characteristics of party building work in colleges and universities and actively explore innovation of network party building work to promote party building work in colleges and universities really into the information age. How to follow the development of the times with the innovation spirit to strengthen party building through the Internet is an urgent task for party building work in colleges and universities in the New Age.

\section{The Practical Significance to Promote the Innovation of Party Building Work in Colleges and Universities with the Aid of the Internet}

It helps to enhance the party's vitality and vigor to realize the modernization of party building work. Using the Internet to promote the innovation of party building work and organizational working method is an important guarantee to practice Scientific Outlook on Development, to achieve modernization of party building work, to reflect the advanced nature of the party, to improve the party's ruling ability and leading level and to continue to instill new vitality in the party. The reality of social development requires us to adapt to the new characteristics of the times and to establish and consolidate the party's ruling status in the Internet's information environment. Colleges and universities should integrate with construction of "Digital Campus", play their own unique advantages and bring forth new working methods to vigorously promote the party building work and enhance the party's vitality and vigor. 
It helps to expand the influence of publicity and education, and master the discourse power of network media. With the growing ranks of student Internet users, some traditional education models, means and methods have difficulty to play an effective role in education for the students. Party building work in colleges and universities plays a leading role in students' ideological and political education. If we cannot actively take up the position of online education, we will gradually reduce the acting points of students' ideological education in colleges and weaken the influence of education. Competition for the discourse power of network media becomes more and more intense and the Western capitalist countries wantonly penetrate ideology and expand their culture by the openness of network environment and by virtue of its advantages of network information resources. Therefore, workers of party building in colleges and universities must start from the strategic development of the party and the country, take the initiative, master the discourse power of network media and make full use of network to serve party building work in colleges and universities in the New Age.

It meets the needs to adapt to new situation to set up a dynamic party members' management mechanism. Under the new situation, there appear some new problems in party building work, especially party members' mobility which poses new challenges to the traditional party building work in colleges and universities. For example, party members studying abroad, taking a business trip in other places or taking internships outside the campus cannot normally take part in organizational life. It becomes more difficult for party organizations to educate and manage them. At the same time, the school system of many campuses for one school brings new challenges to the original party building work in colleges and universities. In addition, with the deepening reform of complete credit system and flexible educational system, student management in colleges and universities is also undergoing a series of changes from class management to community management. Therefore, there is an urgent need to improve and innovate working methods with introducing modern network technology into the party building work to make up for the shortcomings of traditional methods to further explore how to construct a dynamic management mechanism.

\section{Current Problems on Strengthening Party Building Work in Colleges and Universities by Means of the Internet}

The function of websites is single, which are just databases with ineffectiveness. The positioning of some party building websites is mainly an information-distributing platform or electronic database, which can only satisfies general information browsing and query and provides few service content with interaction and practicability, such as online party work, proposals, complaints, supervision and discussion. Certainly, this is relative to the starting stage of party building in some colleges and universities, but the more important thing is that the current positioning of party building websites is not high and lacks interactive content and service awareness.

Some website content is single with the same information and slow update. Some built party building websites lack creativity and apply mechanically superior and other websites. Structurally, they generally include superior spirit, leader speech, document literature, school news, characteristics of other schools and other major sections. In content, they almost exactly reprint superior documents or leader speeches without innovation. On party affairs applications, all 
departments are turf-conscious and Information Island is widespread. Meanwhile, the lack of specially-assigned persons to maintain the website leads to slower update of information resources and monotonous content. Therefore, party building websites cannot really meet the needs of teacher and student members and form a strong attraction, thus resulting in lower traffic and narrow coverage, which cannot achieve the ideal effect to educate party members.

\section{Measures to Improve the Innovation of Party Building with the Help of Internet}

Innovate organizational forms and build a "network party branch". Facing changes of university management system, difficult implementation of party members' organizational life, increasing of floating party members, diverse forms of employment and posts and growing number of retired party members with mobility difficulties, seeking a breakthrough of organizational form in the network and establishing a "network party branch " is an effective supplement of traditional branch model. First, it helps to further strengthen daily learning exchanges between party members, which compensates for the deficiency of conventional organizational life to make party building as well as a variety of educational activities more flexible. Second, it can solve communication problems between floating party members to make them have feeling at home. For example, in order to allow student party members to take advantage of summer vacation and other free time to participate in online learning exchanges, Chongqing University of Technology sets up a website branch called "Youth Red Base".

Innovate network learning platform and enrich party members' studying life. We should set up party members' network learning platform through various channels, establish party member education special websites and link effectively with other excellent sites to share resources of the party building. Enrich and improve functions of teaching and learning platform and focus on creating "network party school". Moreover, create "party member learning room" or "party member digital library" to provide a wealth of learning materials for members. Establish online information publishing special column with political news to guide the majority of party members and young students to know spirit of the center and organizations at all levels with the fastest speed. Build an "online theory of party building research base" to regularly publish research outcomes and trends of theory of party building and guide the majority of party members and young students to pay close attention to theories and master the latest outcomes of theoretical studies, which will guide specific working practices.

Innovate forms of organizational life to make party members' organizational life networked. In order to adapt to the new situation, we can make party members' organizational life networked. Within a certain time, party members can participate in organizational life, talk about learning mutually and exchange ideas in different places through the network. Advantages of such network organizational life are following. First, organizational life is not limited to time and space and members can exchange information with others thousands of miles away. Second, it extends the influence of party organization in space, so that party members studying or working outside may carry out various activities with other members in the same branch through the online branch. Third, it achieves a long-term education for undergraduate party members and they can exchange with others in internship or summer vocation. Fourth, members working outside all the year can get in touch with the party organization through the website and have their own "home." Within a certain range, network organizational life is an important complement to the traditional model of 
organizational life and forms a joint force offline and online.

Innovate methods of ideological report to make ideological report networked. Break the traditional ideological report where members just report to the party organization. We can set up "ideological report zone" on the Internet, which includes members' ideological reports, learning experience, member commitment and rectification measures. A communist serving the people not only reports his or her ideology to the party organization, but also to the masses to accept the investigation of the organization and supervision of the people in practice. The network ideological report is conducive to boosting party members' consciousness to embody and maintain the advanced nature of the party in ideology and behavior. Furthermore, it increases the transparency of party members' educational activities and adheres to the mass line, which helps to form a long-term mechanism of party members' enhancing education and excellent activities.

Innovate the form of democratic appraisal of party members to make democratic appraisal networked. The democratic appraisal of party members includes self-assessment, peer assessment and the evaluation of the masses, which can be achieved through the network. This democratic appraisal form is more open with the masses ready to participate in and party members' ideology and behavior can be effectively supervised, which makes activities of party members truly transparent and open. Primary party organizations and party members rectify and reform conscientiously according to these comments, which facilitate the implementation of advanced education and create excellence. Recently, Chongqing Jiangbei District actively develops and fully implements an Internet operating system called "First Talk Second Comment Third Publish" and establishes a scientific and democratic evaluation system to greatly improve work efficiency, which is worth being used as a reference by party building in colleges and universities.

Innovate the supervision model to make the supervision of the party building networked. Smooth network supervision channels, including the supervision of the masses outside the party and the supervision of party organizations. Use the Internet to carry out party members' advanced nature education campaign and party members' creating excellence activities, which will help the openness of the party affairs and facilitate participation and supervision of the masses. In addition, this can link the party and the masses closely, greatly improve the efficiency of the party, show the advanced nature of the party and build the prestige of the ruling party among the people.

Innovate the payment and management of party membership dues to make party membership dues management networked. Currently, the collection and management of party membership dues is very traditional and backward, especially the collection of floating party members. At the same time, the traditional manual bookkeeping is labor-consuming, time-consuming and cumbersome, which cannot meet the needs of management of dues in the New Age. In view of this, we can develop a special computerized financial system of dues management. The system should do the following things. First, facilitate accounts entry and the query is simple and visualized. Second, the system is tight and easy to operate. Third, it has high accuracy, security and stability in line with the practice of membership dues management to realize computerization of dues management.

Innovate party affairs management and develop a network party affairs management system. 
We should simplify and integrate the tedious daily party affairs management work, develop a network party affairs management system and replace traditional management model with the electronic integrated management model. Network party affairs management system has a complete coverage of basic information management of party members, the management of floating party members, basic information management of party building, information distributing of party building, the educating and training of the active applicants for CPC membership, development of party organizations, daily education and management of party members, the transferring of membership credentials, payment of party membership dues, democratic appraisals, the organizational assessment, organizational life offline, the inner-party supervision, outer- party supervision and exchanges between the party and the masses. We should use two-way operating mechanism with local area network and the Internet according to a confidential and non-confidential content to establish a comprehensive, powerful, all-out, effective website of party building. This will make innovative ideas of the network party building realized.

\section{References}

[1] Li Lin, Hu Meiyan. An Exploration on the Innovative Construction of Network Informationization of Party Building Work in Colleges and University [J]. Ideological Education and Party Building in Schools, 2010, No.33904: 42-44.

[2] Yao Jianying. A Research on the Status and Optimization Strategies of Party Building in Colleges and Universities [J]. Studies in Ideological Education, 2011, No.19001: 45-47.

[3] Tang Jiahai, Song Yuanlin. Characteristics, Status and Strategic Choice of Network Party Building Work in Colleges and Universities [J]. Theory and Practice of Contemporary Education, 2011, v.3; No.2412: 55-58.

[4] Zou Xin. A Research on the Informationization of Party Building Work in Colleges and Universities in the Network Age [J]. Ideological Education and Party Building in Schools, 2009, No.31819: 35-36 + 71 .

[5] Qin Qinhe. A Research of Innovation of Party Building Work in Colleges and Universities from the Perspective of Network [J]. Hunan Social Science, 2013, No.16006: 57-59. 